Available online at https:/jurnal.stmikroyal.ac.id/index.php/jurdimas

\title{
PELATIHAN PEMBUATAN WEBSITE PORTAL DENGAN MENGGUNAKAN WORDPRESS UNTUK SISWA/SISWI SMA NEGERI 6 PALEMBANG
}

\author{
Ahmad Farisi ${ }^{1 *}$, Nur Rachmat ${ }^{2}$, Muhammad Ezar Al Rivan ${ }^{2}$ \\ ${ }^{1}$ Sistem Informasi, Universitas Multi Data Palembang \\ ${ }^{2}$ Teknik Informatika, Universitas Multi Data Palembang \\ email: ahmadfarisi@mdp.ac.id
}

\begin{abstract}
Website is a medium for delivering information that can be accessed online. Websites can be created in various ways, one of those various ways is Content Management System (CMS). CMS is an alternative used to create websites for those who are not familiar with programming. One of the the most widely used CMS platforms is Wordpress. This activity provides training on website creation using Wordpress for students of SMA Negeri 6 Palembang. The methods used in this training are community education and training. This method is used in the form of training and counseling accompanied by demonstrations or joint practice in making websites using WordPress. This activity was started by conducting a needs survey of the training participants to map the needs and expectations of the trainees. Participants also responded to the training process through a post-training questionnaire. Based on the data collected from the questionnaire, most of the participants stated that the material presented in the training was in accordance with the participants' needs, delivered very well, and participants would use WordPress to create a website after the training was conducted.
\end{abstract}

Keywords: CMS; website; wordpress; questionnaire

\begin{abstract}
Abstrak: Website merupakan sarana yang digunakan sebagai media penyampaian informasi yang bisa diakses secara online. Website dapat dibuat dengan berbagai cara, salah satunya menggunakan Content Management System (CMS). CMS merupakan alternatif pembuatan website yang dapat digunakan bagi mereka yang tidak terbiasa dengan pemrograman. Salah satu platform CMS yang paling banyak digunakan adalah Wordpress. Pengabdian masyarakat ini memberikan pelatihan pembuatan website dengan menggunakan Wordpress bagi siswa/siswi SMA Negeri 6 Palembang. Adapun metode yang digunakan dalam pelatihan ini adalah pendidikan masyarakat dan pelatihan. Metode ini digunakan dalam bentuk pelatihan dan penyuluhan yang disertai dengan demonstrasi atau praktik bersama dalam pembuatan website menggunakan Wordpress. Kegiatan ini dimulai dengan melakukan survei kebutuhan peserta pelatihan untuk memetakan kebutuhan dan harapan dari peserta pelatihan. Peserta juga memberikan respon terhadap proses pelatihan melalui kuesioner pasca pelatihan. Berdasarkan data yang dikumpulkan dari kuesioner tersebut, sebagian besar peserta menyatakan bahwa materi yang disampaikan dalam pelatihan telah sesuai dengan kebutuhan peserta, disampaikan dengan sangat baik, dan peserta akan menggunakan Wordpress untuk membuat website setelah pelatihan dilaksanakan.
\end{abstract}

Kata kunci: CMS; website; wordpress; kuesioner 
Jurdimas (Jurnal Pengabdian Kepada Masyarakat) Royal

Vol. 5 No. 1, Januari 2022, hlm. 25 - 32

ISSN 2614-7912 (Print)

DOI: https://doi.org/10.33330/jurdimas.v5i1.1118

ISSN 2622-3813 (Online)

Available online at https:/jurnal.stmikroyal.ac.id/index.php/jurdimas

\section{PENDAHULUAN}

Website atau disingkat web, dapat diartikan sebagai sekumpulan halaman yang yang berisi informasi dalam bentuk data digital, baik berupa text, gambar, video, audio, dan animasi lainnya yang disediakan melalui jalur koneksi internet (Abdullah, 2016).

Saat ini, informasi yang disajikan dalam website dapat diakses melalui berbagai macam perangkat, mulai dari komputer, laptop, hingga perangkat bergerak seperti smartphone. Hal ini membuat akses informasi dari website semakin mudah didapatkan.

Tidak hanya untuk kebutuhan berita dan informasi pada websitewebsite portal berita, saat ini website telah dimanfaatkan oleh berbagai bidang seperti bisnis, pendidikan, lapangan pekerjaan, sosial media, promosi, hingga jual beli online dan bidang-bidang lainnya (Kaplan, 2020).

Dengan kemajuan-kemajuan teknologi website serta semakin banyaknya bidang yang memanfaatkan website, secara tidak langsung minat terhadap pembuatan website juga meningkat. Hal ini ditandai dengan hadirnya begitu banyak platform yang menghadirkan layanan dan kursus pembuatan website di Indonesia.

$$
\text { Pembuatan website dapat }
$$

dilakukan dengan beragam cara. Beberapa cara pembuatan website antara lain (a) menulis kode program melalui serangkaian pemrograman dengan bahasa pemrograman web, (b) menggunakan content management system (CMS), (c) Menggunakan website builder.

Pembuatan website yang dilakukan dengan menulis kode program merupakan cara yang dapat dipilih oleh praktisi teknologi informasi yang telah terbiasa dengan kegiatan pemrograman. CMS merupakan pilihan yang tepat untuk pembuatan website bagi mereka yang tidak terbiasa dengan cara menulis kode program.

CMS adalah suatu sistem yang digunakan untuk mengelola dan memfasilitasi proses pembuatan, pembaharuan, dan publikasi content secara bersama (collaborative content management). Content yang dimaksud merupakan informasi dalam bentuk teks, grafik, gambar maupun dalam formatformat lain yang perlu dikelola dengan tujuan memudahkan proses pembuatan, pembaharuan, distribusi, pencarian, analisis, dan meningkatkan fleksibilitas untuk ditransformasikan ke dalam bentuk lain (Elinawati, Muhammad, \& Arlis, 2015).

Selain menggunakan CMS, pembuatan website juga dapat dilakukan dengan menggunakan website builder yang sudah banyak tersedia saat ini seperti wix.com, godaddy.com, weebly.com, dan lain-lain. Website builder ini memiliki konsep yang sama dengan CMS, namun tidak dapat digunakan secara offline. Sementara CMS dapat digunakan secara offline pada local server sebelum dipublikasi secara online.

Salah satu CMS yang banyak digunakan adalah Wordpress. Saat ini $30 \%$ website di dunia menggunakan WordPress dan Wordpress telah merajai $60 \%$ pengguna CMS di seluruh dunia seperti Joomla, Drupal, Magento dan Shopify (Q-Success, 2021).

Beberapa studi yang memanfaatkan Wordpress juga telah dilakukan, seperti (Sunarti \& Safitri, 2016) yang memanfaatkan Wordpress sebagai media ajar yang terbukti meningkatkan hasil belajar siswa berdasarkan nilai rata-rata siswa yang 
Available online at https://jurnal.stmikroyal.ac.id/index.php/jurdimas

mencapai angka 80,8 dan nilai ketuntasan klasikalnya mencapai $88 \%$. Studi tersebut menyimpulkan bahwa media ajar berbasis Wordpress layak dan dapat digunakan dalam pembelajaran. Studi lainnya juga memanfaatkan Wordpress sebagai media pembuatan blog gratis di Kelurahan Purbayan Baki Sukoharjo sebagai wadah komunikasi warga (Widhoyoko, 2018). Studi tersebut juga merupakan kegiatan pengabdian kepada masyarakat dalam bentuk pelatihan.

Studi lainnya memanfaatkan Wordpress untuk kebutuhan aplikasi penjualan online atau e-commerce seperti studi yang dilakukan oleh (Dharmawan \& Gata, 2020) yang menerapkan Wordpress untuk pengembangan aplikasi penjualan online pada Toko Jaksquare. Studi tersebut menggunakan metode Bussines Model Canvas (BMC) untuk menentukan strategi bisnis yang dapat membantu kelangsungan produksi dan penjualan. Hasil dari studi tersebut adalah website e-commerce yang dapat digunakan oleh pelanggan Toko Jaksquare untuk berbelanja secara online dan melakukan transaksi tanpa adanya batasan waktu dan tempat, serta dapat meningkatkan penjualan dan pemasaran produk.

Wordpress juga digunakan dalam studi (Rahardja, Handayani, \& Ningrum, 2018) yang memanfaatkan Wordpress dalam mengembangkan website iMe (iLearning Media) pada perguruan tinggi sebagai website resmi RCEP yang digunakan untuk memberikan informasi-informasi terkait pelaksanaan TOEFL secara online hingga sistem registrasi TOEFL online. Dengan adanya website iMe yang dikembangkan dalam studi tersebut, halhal yang tidak diinginkan seperti hilangnya data, rusaknya data pendaftar, dan ketidakefisienan waktu dapat dihindari.

Berdasarkan uraian di atas, pengabdian kepada masyarakat ini memberikan pelatihan tentang bagaimana membuat website dengan memanfaatkan CMS Wordpress. Adapun lokasi pengabdian adalah SMA Negeri 6 Palembang yang merupakan salah satu SMA terbaik di Sumatera Selatan (Munte, 2020). Peserta pelatihan merupakan siswa-siswi SMA Negeri 6 Palembang yang tergabung dalam ekstrakurikuler information and communication technology (ICT). Topik pelatihan tentang pelatihan pembuatan website dengan memanfaatkan CMS Wordpress diputuskan setelah melaksanakan diskusi bersama wakil kepala sekolah bidang kesiswaan dan pembina ekstrakurikuler ICT di SMA Negeri 6 Palembang beberapa waktu sebelum pelaksanaan pelatihan.

\section{METODE}

Kegiatan pengabdian kepada masyarakat ini dilakukan dalam bentuk pelatihan. Adapun metode yang digunakan dalam pelatihan ini mengacu pada (Morelli, 2015) adalah pendidikan masyarakat dan pelatihan. Metode ini digunakan dalam bentuk pelatihan dan penyuluhan yang disertai dengan demonstrasi atau praktik bersama dalam pembuatan website menggunakan Wordpress.

Beberapa tahapan yang dilakukan dalam pelaksanaan kegiatan pengabdian kepada masyarakat ini adalah sebagai berikut :

Survei Kebutuhan: dilakukan untuk memetakan kompetensi apa yang dibutuhkan peserta. Pada tahapan inilah 
Available online at https://jurnal.stmikroyal.ac.id/index.php/jurdimas

diputuskan topik pelatihan adalah pembuatan website dengan Wordpress.

Persiapan: yang dilakukan adalah a) persiapan administratif yang dibutuhkan sebagai syarat pelaksanaan pelatihan, b) pembuatan materi pelatihan, c) mempersiapan kuesioner yang akan disebarkan kepada peserta pelatihan pra dan pasca pelatihan.

Pelaksanaan: pelatihan pembuatan website dengan Wordpress dilakukan di SMA Negeri 6 Palembang. Sebelum pelatihan dilaksanakan, terlebih dahulu disebarkan kuesioner yang bertujuan untuk melihat kesiapan dan harapan peserta pelatihan. Secara umum kegiatan pelatihan berlangsung lancar.

Evaluasi: dilakukan setelah pelatihan. Evaluasi dilakukan dengan menyebarkan kuesioner yang bertujuan mengevaluasi pelatihan, baik dari sisi materi pelatihan, hingga cara penyampaian instruktur, serta saran dan kritik dari para peserta kepada tim pengabdi.

\section{PEMBAHASAN}

Pelatihan pembuatan website dengan memanfaatkan Wordpress ini berjalan dengan lancar dan mendapatkan antusias yang tinggi dari para peserta.

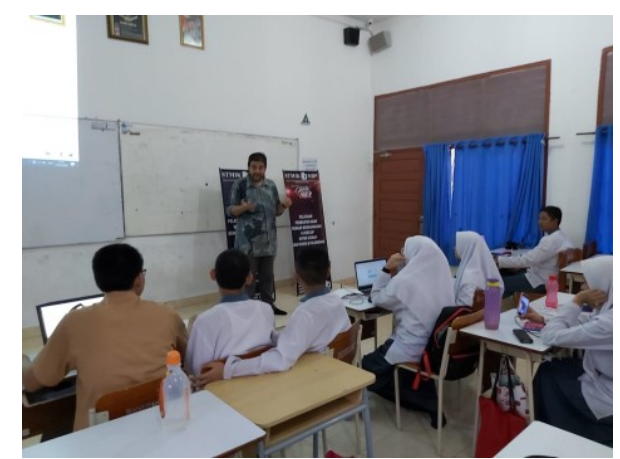

Gambar 1. Suasana kegiatan pelatihan

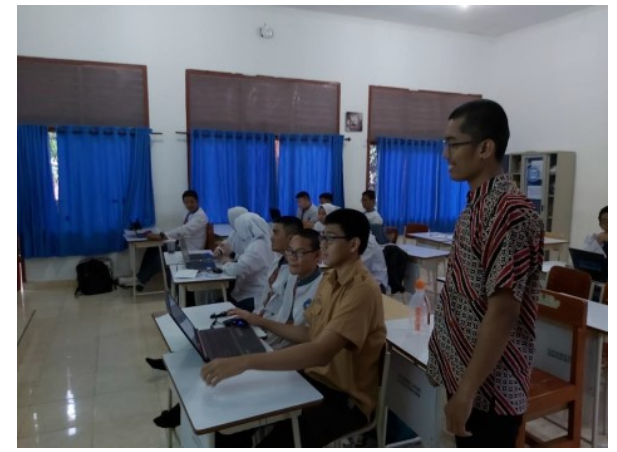

Gambar 2. Pelaksanaan Pelatihan

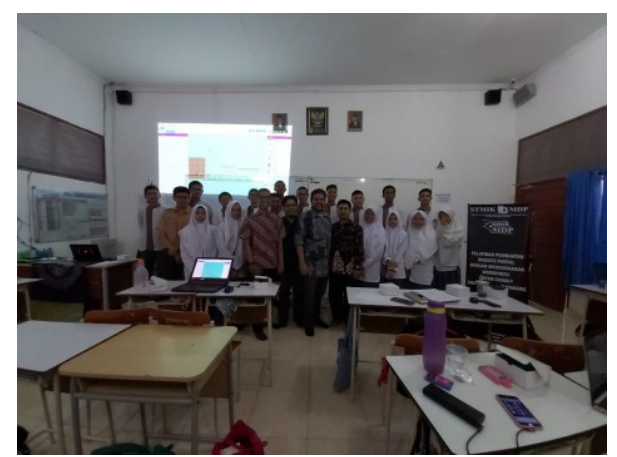

Gambar 3. Foto Bersama Pengabdi dan Peserta Pelatihan

Sebelum pelatihan dimulai, peserta terlebih dahulu diminta untuk mengisi kuesioner pra pelatihan. Terdapat 18 orang peserta yang menjadi responden kuesioner. Adapun hasil kuesioner pra pelatihan dapat dilihat pada Gambar 4.

Hasil Kuesioner Pra Pelatihan Wordpress

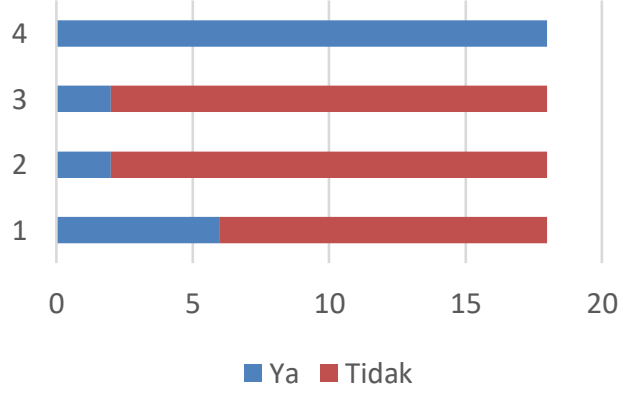

Gambar 4. Hasil Kuesioner Pra Pelatihan 
Jurdimas (Jurnal Pengabdian Kepada Masyarakat) Royal

Vol. 5 No. 1, Januari 2022, hlm. 25 - 32

Available online at https:/jurnal.stmikroyal.ac.id/index.php/jurdimas

Pertanyaan yang diberikan pada kuesioner pra pelatihan tersebut adalah 1) Apakah anda pernah mengetahui tentang Wordpress?, 2) Apakah anda pernah menggunakan Wordpress?, 3) Apakah anda mengerti cara menggunakan Wordpress?, 4) Apa anda tertarik untuk mengikuti pelatihan Wordpress?.

Berdasarkan hasil kuesioner pra pelatihan pada Gambar 4 dapat diketahui bahwa jumlah peserta yang telah mengenali Wordpress sebanyak 6 orang. Dari Gambar 1 juga didapatkan informasi bahwa semua peserta tertarik untuk mengikuti pelatihan ini.

Setelah pelatihan dilaksanakan peserta juga diminta untuk mengisi kuesioner pasca pelatihan yang bertujuan untuk mengevaluasi pelatihan yang telah dilaksanakan. Hasil kuesioner pasca pelatihan tersebut dapat dilihat pada Gambar 5, Gambar 6, Gambar 7, Gambar 8 dan Gambar 9.

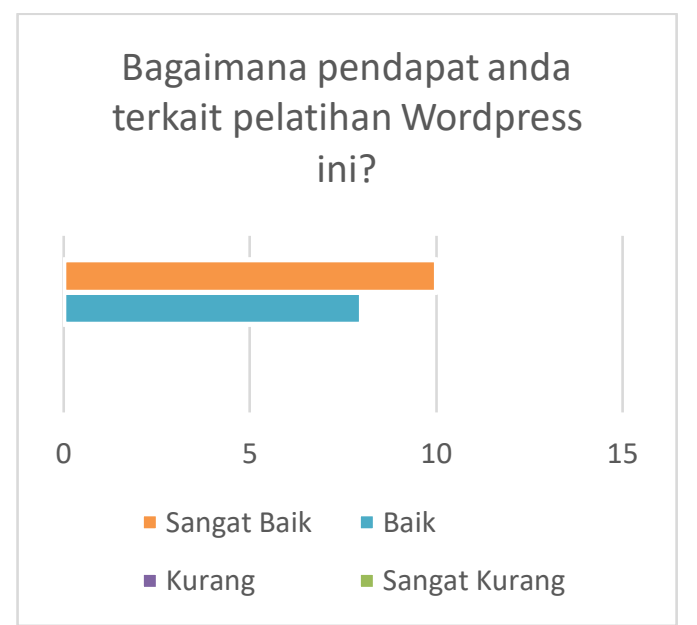

Gambar 5. Hasil Kuesioner Pasca Pelatihan Pertanyaan Pertama

Berdasarkan informasi yang didapatkan dari Gambar 5, dapat diketahui bahwa setelah pelatihan dilaksanakan, 10 orang peserta memberikan respon sangat baik dan 8 orang lainnya memberikan respon baik. Kuesioner ini dilanjutkan dengan pertanyaan tentang kesesuaian antara materi pelatihan yang disampaikan dengan pengetahuan yang dibutuhkan oleh peserta.
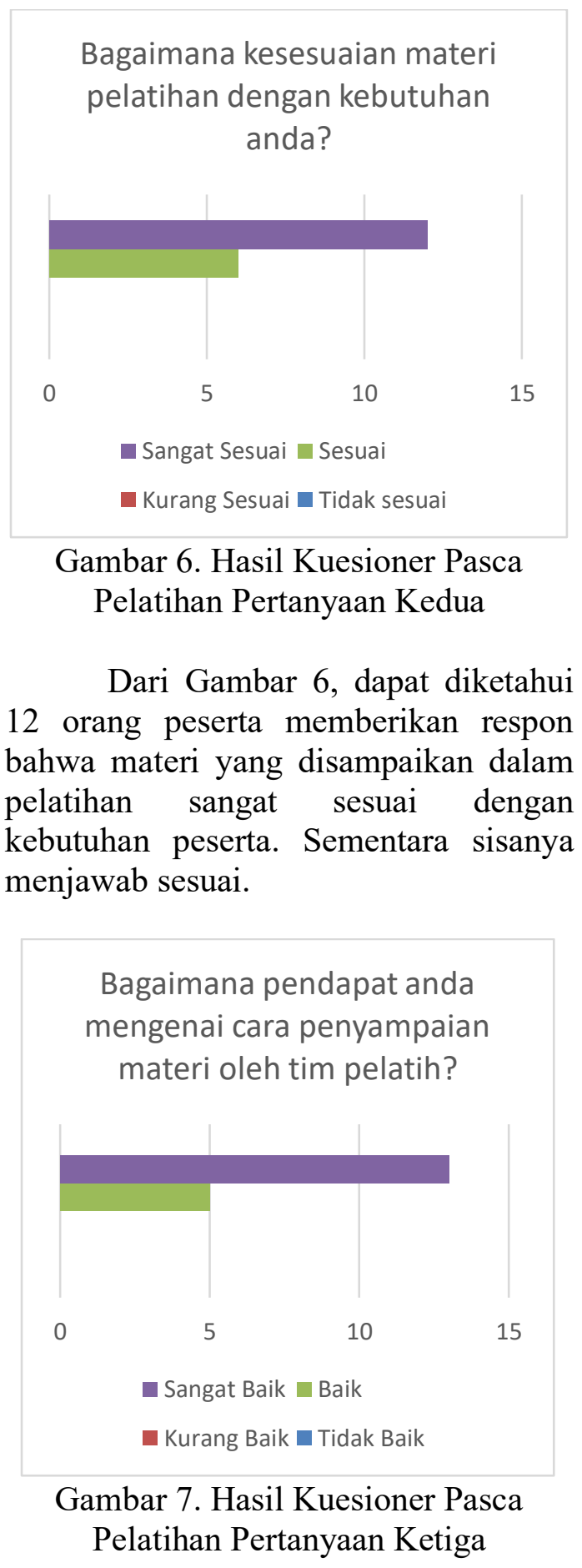
Jurdimas (Jurnal Pengabdian Kepada Masyarakat) Royal

Vol. 5 No. 1, Januari 2022, hlm. 25 - 32

ISSN 2614-7912 (Print)

DOI: https://doi.org/10.33330/jurdimas.v5i1.1118

ISSN 2622-3813 (Online)

Available online at https:/jurnal.stmikroyal.ac.id/index.php/jurdimas

Dari Gambar 7, dapat diketahui bahwa terdapat 13 orang peserta yang menyatakan bahwa instruktur pelatihan dapat menyampaikan materi pelatihan dengan sangat baik, sementara 5 orang peserta lainnya menyatakan baik. Kuesioner ini dilanjutkan dengan menanyakan peserta tentang keinginan peserta untuk menggunakan Wordpress setelah pelatihan dilaksanakan.

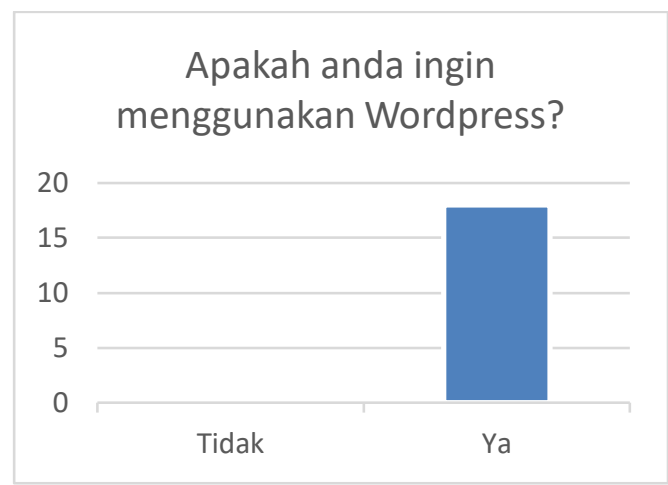

Gambar 8. Hasil Kuesioner Pasca Pelatihan Pertanyaan Keempat

Dari Gambar 8, didapatkan informasi bahwa semua peserta yang telah mengikuti pelatihan ini berminat untuk menggunakan Wordpress dalam membuat website. Kuesioner ini dilanjutkan dengan menanyakan peserta tentang apakah pelatihan yang telah dilakukan telah sesuai dengan harapan peserta.

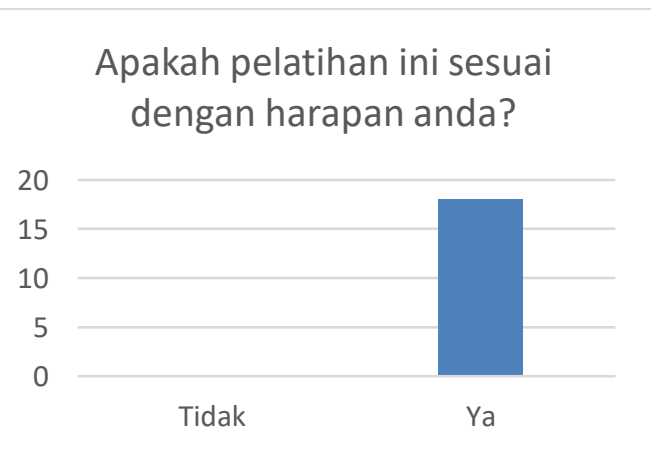

Gambar 9 Hasil Kuesioner Pasca Pelatihan Pertanyaan Kelima
Berdasarkan Gambar 9, diketahui bahwa semua peserta menganggap bahwa pelatihan yang telah dilakukan ini telah sesuai dengan harapan peserta.

Berdasarkan hasil isian kuesioner pasca pelatihan yang telah diuraikan di atas, secara umum peserta menyatakan bahwa pelatihan pembuatan website dengan Wordpress ini berjalan dengan baik, sesuai dengan kebutuhan dan harapan peserta, disampaikan dengan baik, dan menimbulkan keinginan peserta untuk memanfaatkan Wordpress dalam membuat website.

Dari pelatihan ini, para peserta mampu membuat website dengan mudah dan menarik dengan menggunakan Wordpress. Hal ini terbukti dari beberapa hasil karya peserta yang dapat dilihat pada gambar berikut.

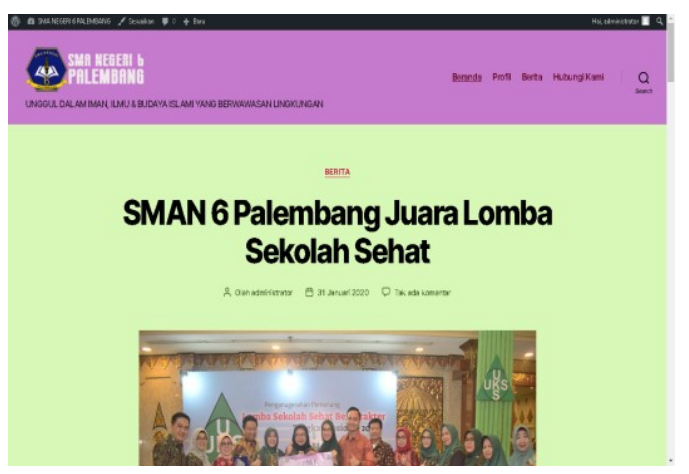

Gambar 10. Halaman Home Page

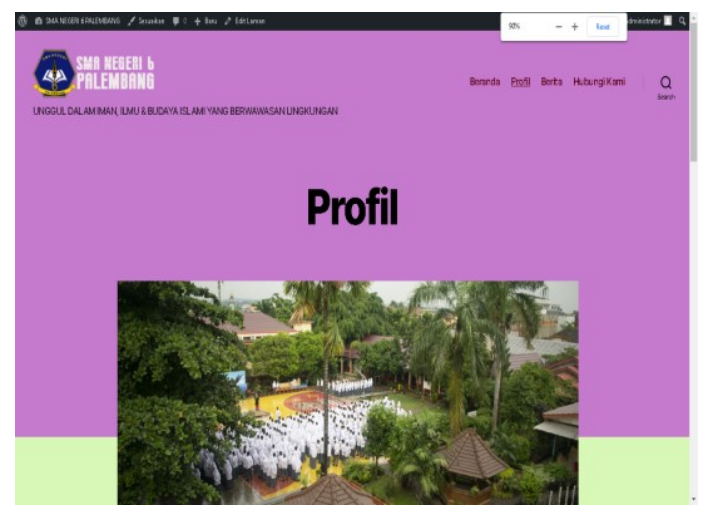

Gambar 11. Halaman Profil 


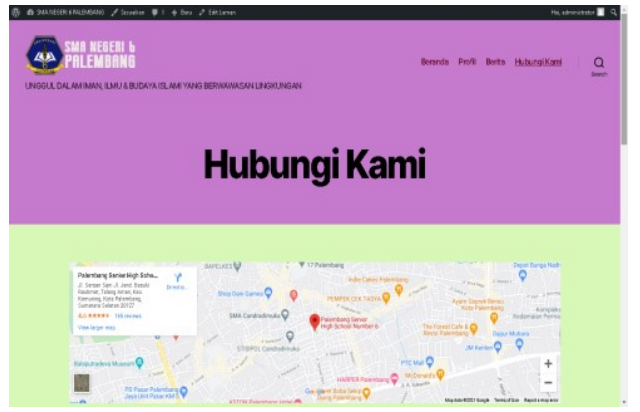

Gambar 12. Halaman Kontak

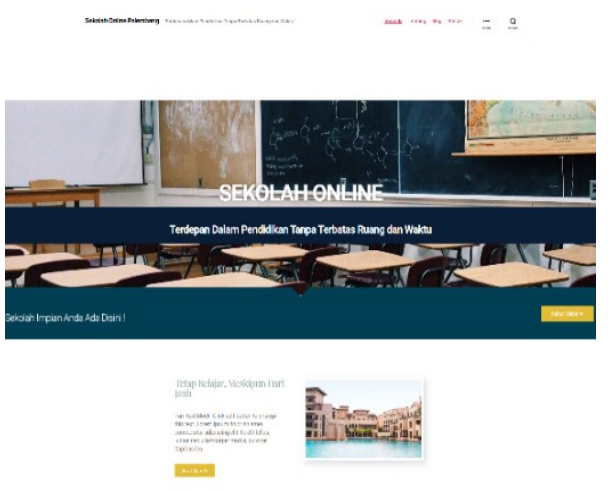

Gambar 13. Halaman Website Karya Peserta

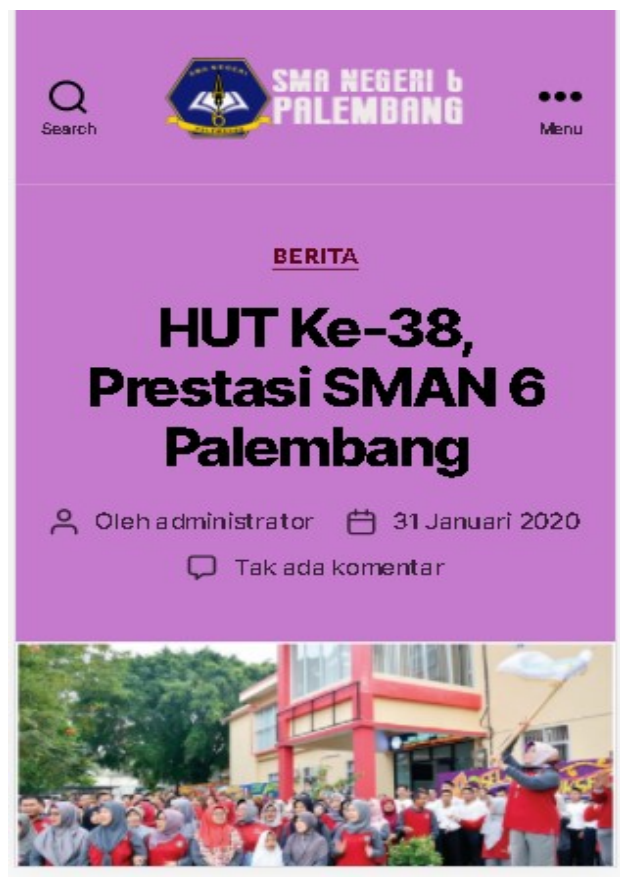

Gambar 14. Halaman Berita dari Perangkat Smartphone
Website hasil karya peserta juga dapat diakses melalui perangkat smartphone dan menunjukkan hasil yang responsif. Website responsif adalah website yang memiliki antar muka responsif meskipun diakses dari berbagai perangkat yang memiliki ukuran resolusi berbeda (Rab, 2018).

\section{SIMPULAN}

Pengabdian kepada masyarakat yang dilaksanakan dalam bentuk pelatihan pembuatan website menggunakan Wordpress bertujuan untuk memberikan pengetahuan dan pemahaman dalam penggunakan Wordpress bagi siswa-siswi SMA Negeri 6 Palembang dalam membuat website. Secara umum, peserta pelatihan dapat menggunakan Wordpress untuk membuat website sendiri tanpa harus memahami konsep dan teori tentang pemrograman. Selain itu, para peserta pelatihan juga antusias dan tertarik mengikuti pelatihan ini dan memberikan respon yang sangat baik berdasarkan data isian kuesioner yang telah dirangkum oleh tim pengabdi.

\section{DAFTAR PUSTAKA}

Abdullah, R. (2016). Easy \& Simple Web Programming. Jakarta: Elex Media Komputindo.

Dharmawan, R., \& Gata, G. (2020). Penerapan Aplikasi Penjualan Online (E-Commerce) Menggunakan Content Management System Wordpress Pada Toko Jaksquare. Jurnal IDEALIS (Indonesia Journal Information System), 3(1), 132138. 
Elinawati, S., Muhammad, A., \& Arlis, S. (2015). Perancangan Content Management System ( Cms ) Dengan Studi Kasus E-Bisnis Pada Toko Alya Gorden. Jurnal KomTekInfo Fakultas Ilmu Komputer, 2(1), 79-90.

Kaplan, K. (2020). Why Every Business Needs A Website. Diambil 19 April 2021, dari forbes.com website:

https://www.forbes.com/sites/the yec/2020/02/03/why-everybusiness-needs-awebsite/?sh $=5$ fc9ee $706 \mathrm{e} 75$

Morelli, N. (2015). Challenges in designing and scaling up community services. Design Journal, 18(2), 269-290. https://doi.org/10.2752/1756306 15X14212498964394

Munte, T. (2020). 11 SMA Terbaik di Sumatera Selatan Sesuai Nilai UTBK 2020. Diambil 19 April 2021, dari tagar.id website: https://www.tagar.id/11-smaterbaik-di-sumatera-selatansesuai-nilai-utbk-2020

Q-Success. (2021). Usage statistics and market share of WordPress. Diambil 19 April 2021, dari W3Techs.com website: https://w3techs.com/technologies /details/cm-wordpress

Rab, S. (2018). A University website using Content Management
System ( CMS ) and add-on plugins (United International University). United International University. Diambil dari http://dspace.uiu.ac.bd/bitstream/ handle/52243/155/MSCSE

Project_Sanjida

Rab_id_012133012.pdf?sequenc $\mathrm{e}=1 \&$ isAllowed $=\mathrm{y}$

Rahardja, U., Handayani, I., \& Ningrum, A. A. (2018). Pemanfaatan Sistem iMe Berbasis WordPress sebagai Official Site RCEP pada Perguruan Tinggi. Creative Information Technology Journal, 4(3), 207. https://doi.org/10.24076/citec.20 $17 \mathrm{v} 4 \mathrm{i} 3.111$

Sunarti, S., \& Safitri, B. R. A. (2016). Pengembangan Media Berbasis Wordpress Untuk Meningkatkan Hasil Belajar Siswa. Lensa: Jurnal Kependidikan Fisika, 4(1), $\quad 46$. https://doi.org/10.33394/jlkf.v4i1.836

Widhoyoko, Y. P. (2018). Pelatihan Pembuatan Blog Menggunakan Template Wordpress Gratis Kepada Pamong Kelurahan Purbayan Baki Sukoharjo Sebagai Wadah Komunikasi Dengan Warga Tahun 2017. ADIWIDYA, II(1), 24-29. 